\title{
Improving The Oral Presentation Skills Of Accounting Students: An Experiment
}

David Christensen, (Email: ChristensenD@suu.edu), Southern Utah University Jeffrey Barnes, (Email: Barnes@suu.edu), Southern Utah University

David Rees, (Email: Rees@ suu.edu), Southern Utah University

Gerald Calvasina, (Email: Calvasina@ suu.edu), Southern Utah University

\begin{abstract}
Numerous surveys of accounting professionals have established the importance of communication skills for newly-hired accounting graduates, and challenge business schools to revise curricula accordingly. To determine if the oral skills of accounting students can be improved, two oral presentation assignments were given to students in six accounting classes at a small western university. The oral presentations were evaluated on ten oral communication skills recently judged by accounting professionals to be most important for new hires to possess. Feedback was provided after the first presentation. Results showed that oral presentation skills improved significantly after the first presentation. Accounting students can improve their oral presentation skills if the accounting faculty is committed to providing timely feedback.
\end{abstract}

\section{INTRODUCTION}<smiles>[c]1ccccc1</smiles>

urvey research has established the importance of communication skills for newly-hired accounting graduates to possess, and condemns business schools for failing to adequately develop the communication competency (Estes 1979, Andrews and Sigband 1984, American Education Change Commission 1990, Siriram and Coppage 1992, Lau and Rans 1993, Siegel and Sorensen 1994, Institute of Management Accountants 1994, Maes et al. 1997, Lee and Blaszczynski 1999, Albrecht and Sack 2000). However, this literature does not identify specific communication skills that are needed by entry-level accountants. A few surveys have attempted to discover the communication skills needed by business graduates, but none has focused on the communication skills needed by accounting graduates. Moreover, in a survey 114 graduates from a business school in the Midwest, Quible (1991) reported that the importance of specific communication skills varied by the type of business and its size. Thus, it appears that the specific communication skills needed by an accountant may not be the same as those needed by other kinds of business graduates.

To identify what skills to emphasize in an accounting curriculum, Christensen and Rees (2002) surveyed members of the Institute of Management Accounting (IMA) and the American Institute of Certified Public Accountants (AICPA) to determine (1) the relative importance of 32 business communication skills cited in business communication literature and (2) the level of satisfaction with college preparation in those skills. Based on mean ratings on two five-point scales, English skills (pertaining to spelling, grammar, and punctuation) were significantly more important than oral/interpersonal and writing skills, and the respondents were least satisfied with the writing skills of newly-hired accountants (Table 1).

To determine if accounting students could improve the writing skills judged most important in the survey, a series of one-page essays was administered to accounting students in four classes during the fall 2002 semester. The need for new hires to develop skills in writing short letters and memos, as opposed to long reports, was stressed by the respondents. Three classes were undergraduate accounting courses (intermediate accounting, cost accounting, 
auditing), and one was a graduate course (advanced managerial accounting). Feedback was provided after each essay. Results showed that the writing skills improved significantly after each essay (Christensen et al, 2004).

To determine if accounting students could improve the oral skills judged most important in the survey, short oral assignments were given to students in six classes during the fall 2003 semester. ${ }^{1}$ The following sections describe our methodology, results, and conclusions.

\section{METHODOLOGY}

We administered two short oral presentation assignments in six accounting classes during the fall semester of 2003. Four classes were undergraduate accounting courses (accounting information systems, auditing, cost accounting, and tax research), and two classes were a graduate course (two sections of advanced managerial accounting).

The experiment was a "one group pretest-posttest design" (Stanley and Campbell 1966), where scores on the first oral presentation were the pretest observation, and scores on the second presentation were the posttest observation. Feedback from the instructor on each student's presentation constituted the treatment. ${ }^{2}$

Students were required to make the first oral presentation near the beginning of the semester and the last presentation near the end of the semester. The presentations were normally no more than five minutes per student, and were usually made as part of a group assignment. At the start of the semester the students were told that the oral presentations would be graded on grammar, business vocabulary, and platform skills, as well as content.

Based on respondent comments from the survey, beginning accounting professionals are often required to speak to clients, supervisors, peers, and prospective employees. These observations were helpful in determining the appropriate kinds of oral presentations for the experiment. Rather than having the same oral presentation topic for all classes, each instructor tailored the topic of the presentation to his course. For example, auditing students explained or summarized auditing standards, tax students described or interpreted sections from the Internal Revenue Code, and cost and management accounting students explained key concepts taken from cost management journals.

A rubric was developed to grade the students on ten oral presentation skills (Table 2). The rubric was adapted from Campbell et al. (2001) to include the skills derived from the survey, and facilitated uniform grading between classes. To measure the grammar skill, the instructor identified the number of grammar errors during the oral presentation and subtracted it from 5. For example, if a student made no grammar errors during the presentation, the score was 5. If a student made two grammar errors, the score was 3 . The remaining skills were subjectively scored by the instructor using a scale of 1 to 5 , where 1 reflected poor competency and 5 reflected high competency. More specific meanings of each score for each of the ten criteria are provided in the rubric.

Students received feedback after the first oral presentation in the form of the scores and instructor's notes on the rubric. No class time was spent trying to teach oral communication skills. All of the students had completed at least one oral communication course as part of the general education requirement at the university. Each instructor graded the oral presentations from his own course and tried to grade consistently.

The expectation was that the oral communication skills of the students would improve as they received feedback. To test this expectation, we computed the difference between the posttest and pretest scores for each student for each oral presentation and then computed the mean difference, as indicted below:

Mean difference $=\sum($ Posttest score - Pretest score $) /$ Total number of students in experiment

The mean difference for each skill was tested using the paired t-test and the Wilcoxon signed rank test at an alpha of 0.05 (Sheskin 2000). ${ }^{3}$ For all skills, a positive difference between the last presentation and the first

\footnotetext{
${ }^{1}$ A sample of respondent comments concerning the importance of oral communication skills is in the appendix to this paper.

${ }^{2}$ The internal validity of our experiment was reduced by the absence of randomization and a control group.
} 
presentation implied improvement. For example, if the score on the second presentation was 4 and the score on the first presentation was 3 , the difference of 1 implied improvement. The formal hypotheses and interpretation were as follows:
Hypotheses
Measure
Interpretation
Ho:
Mean difference $\leq 0 \quad$ The oral communication skill did not improve significantly
Ha:
Mean difference $>0 \quad$ The oral communication skill improved significantly

If Ho was rejected at an alpha of 0.05 , then the skill improved significantly.

\section{RESULTS}

The results of the hypothesis tests are presented in Table 3 and Figure 1. The mean differences for skills 2 through10 were significant (one-tailed $\mathrm{p}<0.05$ ), indicating that the students were able to demonstrate improved abilities to use appropriate business vocabulary (skill 2), establish rapport (skill 3), use appropriate voice quality (skill 4), establish eye contact (skill 5), use appropriate body language (skill 6), demonstrate command and understanding of the material presented (skills 7 and 8), organize the material appropriately (skill 9), and present himself or herself in a professional manner (skill 10). The results of the Wilcoxon test were consistent with the results of the paired-t test. ${ }^{4}$

The mean difference score for grammar (skill 1) was also positive, but not significant. We found it extremely difficult to identify grammar errors during the oral presentations. This difficulty may account for the lack of measurable significant improvement for the grammar skill.

A post-test questionnaire was administered to students in the experiment. Using a five-point scale, students were asked to indicate the degree to which the oral assignments helped improve their abilities in each of the 10 skills. As shown in Table 4, the majority of the students felt that their skills improved. The students also indicated that the feedback from the grading rubric was effective in helping them improve their skills.

\section{CONCLUSION}

The oral presentation skills of the accounting students in our one-semester experiment improved significantly as the students received regular feedback from their instructors. These results are similar to the results of writing-skill improvement initiatives (e.g., Laufer and Crosser 1990, Riordan 2000, Christensen et al. 2004), often described as "writing-across-the-curriculum" or "writing-within-the-discipline" (Britton et al. 1975). By writing about a topic within their discipline, students "learn to write" and "write to learn." Similarly, by talking about a topic and explaining it to others, students "learn to talk" and "talk to learn." The process can improve student comprehension of a topic because it forces the speaker to retrieve, organize, and express the topic internally (Emig 1977, Odell 1980).

Some educators may reject initiatives to develop the oral communication skills of accounting students because evaluating oral communication skills is a job best left to communication professors, or because it's too time consuming. We suggest that oral communication assignments on accounting topics cannot be adequately evaluated by non-accountants. In addition, employers of accounting graduates indicate that accounting students need as many communication opportunities before employment as they can get. For institutions that hold student learning as their primary mission, requiring students to explain and write about the topics they are studying is an effective strategy. We also note that the grading rubric was an effective evaluation and grading tool. It provided excellent feedback to students and was very efficient to use.

\footnotetext{
${ }^{3}$ Although the paired-t test is generally reported to be robust to minor violations of normality and equal variance, we chose to also use the nonparametric Wilcoxon test to strengthen our conclusions.

${ }^{4}$ Tables summarizing the results of the difference tests for each of the accounting classes are available from the authors.
} 
Based on its review of undergraduate education, the Boyer Commission (1998:23) recommended that instructors pay more attention to communication skills:

From the freshman seminar to the senior capstone course, communication skills should be integrated with the subject matter. Freshman composition must be cast in a new form intimately related to the student's other courses. Instructors throughout the curriculum need to build opportunities for written and oral presentations into their course outlines, so that experience and confidence can grow continuously.

We support this recommendation.

\section{REFERENCES}

1. Albrecht, W., and R. Sack. 2000. Accounting education: charting the course through a perilous future. Accounting Education Series 16. Sarasota, Florida: American Accounting Association.

2. American Education Change Commission (AECC). 1990. Objectives of education for accountants: Position statement number one. Issues in Accounting Education (fall): 307-312.

3. Andrews, J., and N. Sigband. 1984. How effectively does the new accountant communicate? Perceptions by practitioners and academics. Journal of Business Communication 21 (spring): 15-24.

4. Boyer Commission. 1998. Reinventing undergraduate education: a blueprint for America's research universities. http://notes.cc.sunysb.edu/Pres/boyer.nsf

5. Britton, J., T. Burgess, N. Martin, A. McLeod, and H. Rosen. 1975. The Development of Writing Abilities. London: Macmillian Education.

6. Campbell, K., D. Mothersbaugh, C. Brammer, and T. Taylor. 2001. Peer versus self-assessment of oral business presentation performance. Business Communication Quarterly 64 (September): 23-42.

7. Christensen, D., and D. Rees. 2002. An analysis of the business communication skills needed by entry-level accountants. Mountain Plains Journal of Business and Economics (fall): 1-13.

8. Christensen, D., D. Rees, and J. Barnes. 2004. Improving the writing skills of accounting students: an experiment. Journal of College Teaching and Learning. Forthcoming.

9. $\quad$ Emig, J. 1977. Writing as a mode of learning. College Composition and Communication 28 (May): 122128.

10. Estes, R. 1979. The profession's changing horizons: A survey of practitioners on the present and future importance of selected knowledge and skills. The International Journal of Accounting Education and Research (spring): 47-70.

11. Institute of Management Accountants and Financial Executives Institute. 1994. What Corporate America Wants in Entry-Level Accountants. Montvale, NJ: Institute of Management Accountants.

12. Lau, R. and D. Rans. 1993. They can add but can they communicate? Business Forum 18: 24-26.

13. Laufer, D., and R. Crosser. 1990. The writing-across-the-curriculum concept in accounting and tax courses. Journal of Education for Business (November-December): 83-87.

14. Lee, D., and C. Blaszczynski. 1999. Perspectives of fortune 500 executives on the competency requirements of accounting graduates. Journal of Education for Business 75 (November/December): 104107.

15. Maes, J., T. Weldy, and M. Icenogle. 1997. A managerial perspective: oral communication competency is most important for business students in the workplace. Journal of Business Communication 34: 67-80.

16. Odell, L. 1980. The process of writing and the process of learning. College Composition and Communication 31 (February): 42-50.

17. Quible, Z. 1991. Writing competencies needed by business employees. Delta Pi Epsilon Journal 33: 35-51.

18. Riordan, D., M. Riordan, and M. Sullivan. 2000. Writing across the accounting curriculum: an experiment. Business Communication Quarterly 63 (Sep): 49-59.

19. Sheskin, D. 2000. Handbook of parametric and nonparametric statistical procedures. $2^{\text {nd }}$ Edition. New York: CRC Press.

20. Siegel, G., and J. Sorensen. 1994. What corporate America wants in entry-level accountants. Management Accounting (September): 26-31. 
21. Siriram, R. and R. Coppage. 1992. A comparison of educators' and CPA practitioners' views on communication training in the accounting curriculum. Journal of Applied Business Research (summer): 111 .

22. Stanely, D. and J. Campbell. 1966. Experimental and Quasi-experimental Designs for Research. Chicago: Rand McNally College Publishing Company.

TABLE 1

BUSINESS COMMUNICATION SKIILS NEEED BY NEWLY-HIRED ACCOUNTANTS

\begin{tabular}{|c|c|c|c|c|c|c|}
\hline \multirow[b]{2}{*}{ Communication Skills } & \multicolumn{3}{|c|}{ Importance } & \multicolumn{3}{|c|}{ Satisfaction } \\
\hline & $N$ & Mean & $\sigma$ & $n$ & Mean & $\sigma$ \\
\hline Listens effectively & 2120 & 4.51 & 0.637 & 1883 & 3.04 & 1.107 \\
\hline $\begin{array}{l}\text { Uses correct grammar in both spoken and written } \\
\text { communication }\end{array}$ & 2172 & 4.48 & 0.657 & 1959 & 2.96 & 1.181 \\
\hline Writes well - clearly, concisely, correctly, completely & 2110 & 4.42 & 0.713 & 1881 & 2.68 & 1.092 \\
\hline Produces correctly spelled documents & 2180 & 4.35 & 0.829 & 1992 & 3.47 & 1.137 \\
\hline Asks appropriate questions when talking with customers & 2068 & 4.22 & 0.805 & 1831 & 3.16 & 0.972 \\
\hline Organizes information into effective sentences and paragraphs & 2115 & 4.20 & 0.771 & 1876 & 2.86 & 1.072 \\
\hline Uses an effective business vocabulary & 2181 & 4.16 & 0.803 & 1989 & 3.12 & 1.077 \\
\hline Punctuates documents properly & 2177 & 3.99 & 0.874 & 1992 & 3.26 & 1.112 \\
\hline Asks appropriate questions when talking with supervisors & 2119 & 3.97 & 0.823 & 1890 & 3.33 & 0.998 \\
\hline Edits and revises documents conscientiously & 2045 & 3.94 & 0.865 & 1811 & 2.91 & 1.065 \\
\hline Organizes presentations effectively & 1892 & 3.86 & 0.849 & 1622 & 3.27 & 0.943 \\
\hline Writes naturally and on the reader's level & 2033 & 3.64 & 0.898 & 1781 & 3.02 & 0.970 \\
\hline Establishes rapport with the audience & 1889 & 3.59 & 0.950 & 1618 & 3.26 & 0.838 \\
\hline Objectively presents information in oral reports & 1886 & 3.58 & 0.884 & 1626 & 3.35 & 0.848 \\
\hline Maintains eye contact & 2089 & 3.58 & 0.866 & 1837 & 3.53 & 0.908 \\
\hline Uses effective techniques in writing reports & 1976 & 3.52 & 0.895 & 1713 & 3.03 & 0.907 \\
\hline Composes at the keyboard & 2083 & 3.47 & 1.151 & 1800 & 3.69 & 1.004 \\
\hline Writes persuasively & 1971 & 3.40 & 1.001 & 1682 & 2.90 & 0.892 \\
\hline Is poised; controls nervousness & 2043 & 3.39 & 0.904 & 1795 & 3.44 & 0.861 \\
\hline Uses the telephone and intercom effectively & 2058 & 3.39 & 0.966 & 1799 & 3.53 & 0.941 \\
\hline Uses appropriate tone of voice -conversational or formal & 2060 & 3.37 & 0.899 & 1810 & 3.45 & 0.880 \\
\hline Analyzes the audience before, during, and after an oral report & 1867 & 3.36 & 1.039 & 1589 & 3.05 & 0.879 \\
\hline Provides effective transition between ideas & 2007 & 3.31 & 0.875 & 1752 & 3.07 & 0.882 \\
\hline $\begin{array}{l}\text { Uses appropriate body actions in interpersonal oral } \\
\text { communication }\end{array}$ & 2030 & 3.19 & 0.921 & 1767 & 3.40 & 0.821 \\
\hline Uses voice effectively for emphasis (speech, pitch, volume) & 2014 & 3.18 & 0.879 & 1756 & 3.46 & 0.824 \\
\hline Writes routine letters - order acknowledgement, inquiry, etc. & 1919 & 3.11 & 1.044 & 1636 & 3.19 & 0.920 \\
\hline Uses proper placement and format for letters and reports & 1986 & 3.06 & 1.045 & 1695 & 3.26 & 0.897 \\
\hline Uses audiovisual aids effectively & 1785 & 2.93 & 0.964 & 1471 & 3.49 & 0.881 \\
\hline Creates bibliographies or finds references & 1703 & 2.71 & 1.120 & 1360 & 3.16 & 0.841 \\
\hline Uses jargon in appropriate situations & 1931 & 2.58 & 1.050 & 1552 & 3.20 & 0.765 \\
\hline Outlines material before composing techniques & 1939 & 2.42 & 1.086 & 1488 & 3.06 & 0.811 \\
\hline Uses longhand to create draft of document & 1791 & 1.23 & 0.628 & 955 & 3.24 & 0.706 \\
\hline
\end{tabular}

* Importance $>3$ and satisfaction $<3$

Importance was rated on a five-point scale, where

$1=$ unimportant, 2 = somewhat unimportant, $3=$ important, $4=$ very important, and $5=$ extremely important

Satisfaction was rated on a five-point scale, where

$1=$ very dissatisfied, 2 = somewhat dissatisfied, $3=$ neither satisfied nor dissatisfied, $4=$ somewhat satisfied, and $5=$ very satisfied 
TABLE 2

ORAL COMMUNICATIONS SKILLS GRADING RUBRIC 5

\begin{tabular}{|c|c|c|c|c|c|}
\hline \multicolumn{6}{|c|}{ 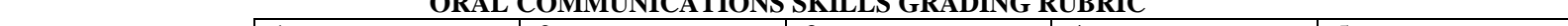 } \\
\hline & 1 & 2 & 3 & 4 & 5 \\
\hline \multicolumn{6}{|l|}{ Mechanics } \\
\hline 1. Grammar & Four or more errors & Three errors & Two errors & One error & No errors \\
\hline $\begin{array}{l}\text { 2. Business } \\
\text { vocabulary (e.g., } \\
\text { appropriate use of } \\
\text { technical jargon) }\end{array}$ & $\begin{array}{l}\text { Completely } \\
\text { inappropriate use of } \\
\text { technical jargon. } \\
\text { Excessive slang. } \\
\text { Profanity. }\end{array}$ & $\begin{array}{l}\text { Somewhere between } \\
\text { completely } \\
\text { inappropriate and } \\
\text { occasionally } \\
\text { inappropriate. }\end{array}$ & $\begin{array}{l}\text { Occasionally } \\
\text { inappropriate use of } \\
\text { technical jargon } \\
\text { Some slang. }\end{array}$ & $\begin{array}{l}\text { Mostly } \\
\text { appropriate. }\end{array}$ & $\begin{array}{l}\text { Completely } \\
\text { appropriate use of } \\
\text { jargon. No slang. No } \\
\text { profanity. }\end{array}$ \\
\hline \multicolumn{6}{|l|}{ Platform skills } \\
\hline $\begin{array}{l}\text { 3. Rapport (e.g., } \\
\text { audience attention } \\
\text { or involvement, and } \\
\text { an appropriate } \\
\text { greeting or } \\
\text { introduction) }\end{array}$ & $\begin{array}{l}\text { No attempt to } \\
\text { establish rapport } \\
\text { with audience. No } \\
\text { introduction or } \\
\text { greeting. Audience } \\
\text { completely } \\
\text { disinterested or not } \\
\text { involved. }\end{array}$ & $\begin{array}{l}\text { Somewhere between } \\
\text { no rapport and some } \\
\text { rapport. }\end{array}$ & $\begin{array}{l}\text { Some rapport } \\
\text { established thru the } \\
\text { use of humor, } \\
\text { greeting, or other } \\
\text { techniques. Some } \\
\text { audience } \\
\text { involvement. }\end{array}$ & $\begin{array}{l}\text { Somewhere } \\
\text { between some } \\
\text { rapport and } \\
\text { completely } \\
\text { engaging. }\end{array}$ & $\begin{array}{l}\text { Completely engaged } \\
\text { audience's attention. } \\
\text { Greeting or other } \\
\text { techniques was } \\
\text { effective. }\end{array}$ \\
\hline 4. Voice qualities & $\begin{array}{l}\text { Poor. Halting, } \\
\text { uneven pace. Can } \\
\text { not hear all the } \\
\text { words due to } \\
\text { mumbling, speaking } \\
\text { too softly, too } \\
\text { quickly, or in } \\
\text { monotone. }\end{array}$ & $\begin{array}{l}\text { Somewhere between } \\
\text { poor and adequate } \\
\text { voice qualities. }\end{array}$ & $\begin{array}{l}\text { Adequate pace and } \\
\text { volume. Speaks } \\
\text { fairly clearly, but } \\
\text { lacks sufficient } \\
\text { variations in vocal } \\
\text { intonation for } \\
\text { emphasis. }\end{array}$ & $\begin{array}{l}\text { Somewhere } \\
\text { between adequate } \\
\text { and excellent voice } \\
\text { qualities. }\end{array}$ & $\begin{array}{l}\text { Fluid, natural } \\
\text { delivery. Speaks } \\
\text { moderately slowly } \\
\text { with good vocal } \\
\text { variety, articulation, } \\
\text { and volume. }\end{array}$ \\
\hline 5. Eye contact & $\begin{array}{l}\text { No eye contact. } \\
\text { Reads continuously. } \\
\text { Stares at ceiling or } \\
\text { at slide screen. }\end{array}$ & $\begin{array}{l}\text { Somewhere between } \\
\text { no and moderate eye } \\
\text { contact. }\end{array}$ & $\begin{array}{l}\text { Moderate eye } \\
\text { contract. Either } \\
\text { faces audience but } \\
\text { refers to notes or } \\
\text { slides occasionally, } \\
\text { or turns body } \\
\text { sometimes at screen. }\end{array}$ & $\begin{array}{l}\text { Somewhere } \\
\text { between moderate } \\
\text { and continuous eye } \\
\text { contact. }\end{array}$ & $\begin{array}{l}\text { Continuous eye } \\
\text { contact. Faces } \\
\text { audience. Rarely } \\
\text { refers to notes. Rarely } \\
\text { glances away from } \\
\text { audience. }\end{array}$ \\
\hline $\begin{array}{l}\text { 6. Body language; } \\
\text { poise }\end{array}$ & $\begin{array}{l}\text { Distracting. Sways, } \\
\text { paces, or fidgets so } \\
\text { that audience is } \\
\text { distracted from } \\
\text { presentation. Poor } \\
\text { use of hands. }\end{array}$ & $\begin{array}{l}\text { Somewhere between } \\
\text { distracting and } \\
\text { neutral body } \\
\text { language. }\end{array}$ & $\begin{array}{l}\text { Neutral. Faces } \\
\text { audience. } \\
\text { Occasionally uses } \\
\text { hands and body } \\
\text { movements } \\
\text { appropriately, but } \\
\text { may still be a bit }\end{array}$ & $\begin{array}{l}\text { Somewhere } \\
\text { between neutral } \\
\text { and engaging body } \\
\text { language. }\end{array}$ & $\begin{array}{l}\text { Engaging. Uses } \\
\text { gestures and } \\
\text { expressions to } \\
\text { enhance presentation. } \\
\text { Speaker looks } \\
\text { comfortable and } \\
\text { natural. }\end{array}$ \\
\hline \multicolumn{6}{|l|}{ Content } \\
\hline $\begin{array}{l}\text { 7. Command of } \\
\text { material (e.g., the } \\
\text { amount of reading) }\end{array}$ & $\begin{array}{l}\text { Poor. Struggles } \\
\text { often to find words. } \\
\text { Reads most of } \\
\text { presentation. }\end{array}$ & $\begin{array}{l}\text { Somewhere between } \\
\text { poor and adequate } \\
\text { command of } \\
\text { material. }\end{array}$ & $\begin{array}{l}\text { Reads small parts of } \\
\text { material. } \\
\text { Occasionally } \\
\text { struggles to find } \\
\text { words. }\end{array}$ & $\begin{array}{l}\text { Somewhere } \\
\text { between adequate } \\
\text { and excellent } \\
\text { command of } \\
\text { material. }\end{array}$ & $\begin{array}{l}\text { Excellent. Does not } \\
\text { read from notes or } \\
\text { slides. Expresses } \\
\text { ideas fluently in own } \\
\text { words. }\end{array}$ \\
\hline $\begin{array}{l}\text { 8. Understanding } \\
\text { (e.g., the accuracy } \\
\text { of statements and } \\
\text { the coverage of the } \\
\text { topic) }\end{array}$ & $\begin{array}{l}\text { Poor. Major topics } \\
\text { or concepts were } \\
\text { inaccurately } \\
\text { described or } \\
\text { explained, or } \\
\text { completely omitted. }\end{array}$ & $\begin{array}{l}\text { Somewhere between } \\
\text { poor and adequate } \\
\text { understanding and } \\
\text { coverage of topic }\end{array}$ & $\begin{array}{l}\text { A few topics or } \\
\text { concepts were } \\
\text { inaccurately } \\
\text { described, or } \\
\text { omitted. }\end{array}$ & $\begin{array}{l}\text { Somewhere } \\
\text { between adequate } \\
\text { and excellent } \\
\text { understanding and } \\
\text { coverage }\end{array}$ & $\begin{array}{l}\text { Excellent } \\
\text { understanding and } \\
\text { coverage. No topics } \\
\text { or concepts were } \\
\text { inaccurately } \\
\text { described or omitted. }\end{array}$ \\
\hline $\begin{array}{l}\text { 9. Organization } \\
\text { (e.g., the relevance } \\
\text { of the material, and } \\
\text { structure of the } \\
\text { presentation) }\end{array}$ & $\begin{array}{l}\text { Poor. Purpose not } \\
\text { clear. Information } \\
\text { disjointed or } \\
\text { inadequate. No } \\
\text { summary or } \\
\text { conclusion. }\end{array}$ & $\begin{array}{l}\text { Somewhere between } \\
\text { poor and adequate } \\
\text { content. }\end{array}$ & $\begin{array}{l}\text { Adequate. } \\
\text { Information is } \\
\text { usually relevant and } \\
\text { appropriate to } \\
\text { audience. The } \\
\text { presentation had } \\
\text { reasonable structure. }\end{array}$ & $\begin{array}{l}\text { Somewhere } \\
\text { between adequate } \\
\text { and engaging } \\
\text { content. }\end{array}$ & $\begin{array}{l}\text { Engaging. } \\
\text { Information is } \\
\text { relevant to audience. } \\
\text { Excellent details. } \\
\text { Presentation included } \\
\text { introduction, main } \\
\text { body, and conclusion. }\end{array}$ \\
\hline $\begin{array}{l}\text { 10. Other (e.g., } \\
\text { dress, visual aids) }\end{array}$ & $\begin{array}{l}\text { Unacceptable. } \\
\text { Numerous problems } \\
\text { degraded the quality } \\
\text { of the presentation. }\end{array}$ & $\begin{array}{l}\text { At least one major } \\
\text { problem degraded } \\
\text { the quality of the } \\
\text { presentation. }\end{array}$ & $\begin{array}{l}\text { Acceptable. A few } \\
\text { minor problems } \\
\text { were noticed. }\end{array}$ & $\begin{array}{l}\text { Somewhere } \\
\text { between } \\
\text { acceptable and no } \\
\text { problems }\end{array}$ & $\begin{array}{l}\text { No problems were } \\
\text { noticed. }\end{array}$ \\
\hline
\end{tabular}

\footnotetext{
${ }^{5}$ Adapted from Campbell et al. (2001). Other comments from instructor.
} 
TABLE 3

RESULTS OF DIFFERENCE TESTS

\begin{tabular}{|c|c|c|c|c|c|c|c|c|c|c|c|}
\hline \multirow[b]{2}{*}{ Skill } & \multirow[b]{2}{*}{$N$} & \multicolumn{2}{|c|}{ Posttest } & \multicolumn{2}{|c|}{ Pretest } & \multicolumn{2}{|c|}{ Difference } & \multicolumn{2}{|c|}{ Paired T Test } & \multicolumn{2}{|c|}{ Wilcoxon Test } \\
\hline & & Mean & Std Dev & Mean & Std Dev & Mean & Std Dev & $T$ & 1-tailed P & $Z$ & 1-tailed $P$ \\
\hline 1. Grammar & 85 & 4.91 & .332 & 4.84 & .459 & .07 & 0.530 & 1.228 & 0.112 & -1.209 & 0.114 \\
\hline 2. Business vocabulary & 85 & 4.82 & .413 & 4.67 & .605 & .15 & 0.664 & 2.124 & 0.019 & -2.051 & 0.020 \\
\hline 3. Rapport & 85 & 4.41 & .745 & 3.98 & .886 & .43 & 0.851 & 4.714 & 0.000 & -4.219 & 0.000 \\
\hline 4. Voice quality & 85 & 4.66 & .589 & 4.25 & .830 & .41 & 0.660 & 5.752 & 0.000 & -4.843 & 0.000 \\
\hline 5. Eye contact & 85 & 4.46 & .646 & 4.15 & .893 & .31 & 0.887 & 3.180 & 0.001 & -2.988 & 0.002 \\
\hline 6. Body language; poise & 85 & 4.51 & .684 & 4.26 & .849 & .25 & 0.830 & 2.746 & 0.004 & -2.660 & 0.004 \\
\hline 7. Command of material & 85 & 4.36 & .784 & 3.91 & .781 & .45 & 1.018 & 4.154 & 0.000 & -3.612 & 0.000 \\
\hline 8. Understanding & 85 & 4.68 & .468 & 4.20 & .613 & .48 & 0.734 & 6.061 & 0.000 & -5.077 & 0.000 \\
\hline 9. Organization & 85 & 4.74 & .467 & 4.21 & .656 & .53 & 0.717 & 6.808 & 0.000 & -5.468 & 0.000 \\
\hline 10. Other & 85 & 4.72 & .478 & 4.55 & .500 & .17 & 0.484 & 3.136 & 0.001 & -2.985 & 0.002 \\
\hline All & 850 & 4.63 & .601 & 4.30 & .773 & .33 & 0.765 & 12.421 & 0.000 & -11.284 & 0.000 \\
\hline
\end{tabular}

Figure 1. Presentation Skills

\section{Presentation Skills $\quad \square$ Pretest \\ $\square$ Postest}

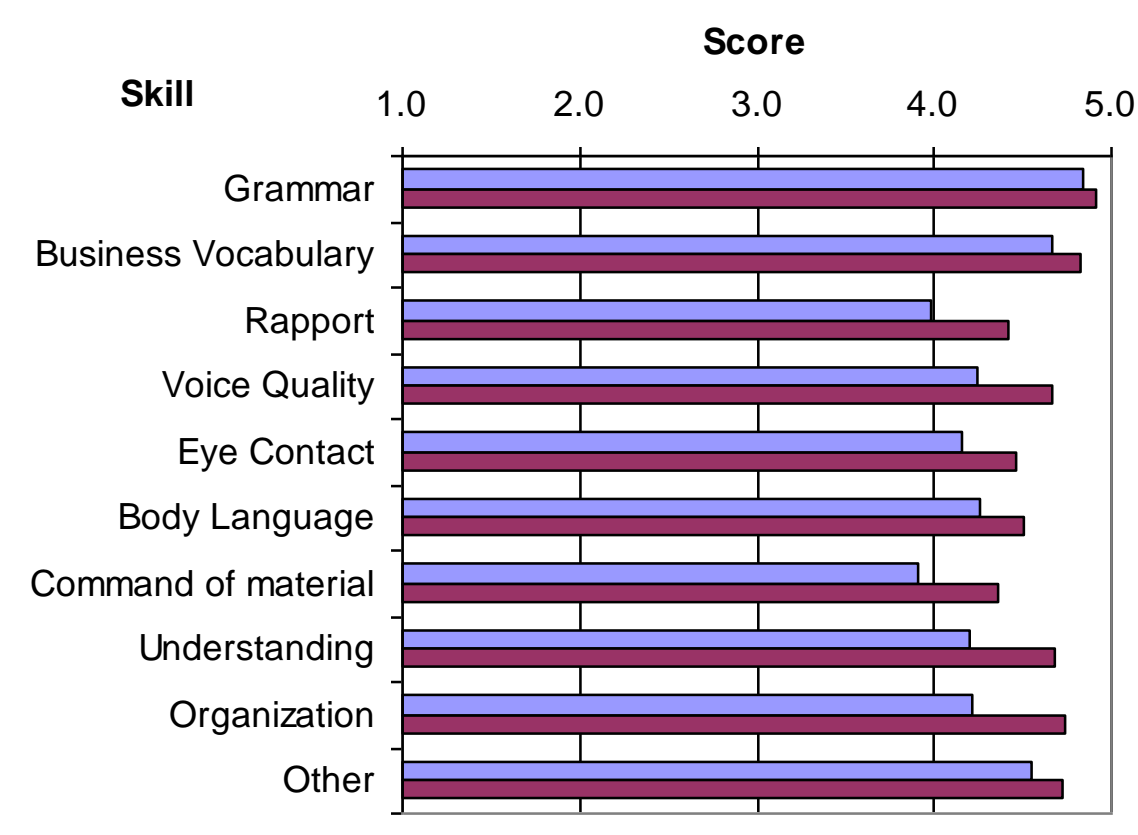




\section{TABLE 4}

\section{RESULTS OF POST-TEST QUESTIONNAIRE}

\begin{tabular}{|c|c|c|}
\hline \multicolumn{2}{|r|}{ The oral presentations helped me improve my ability to } & $\begin{array}{c}\text { Mean } \\
\text { Response* }\end{array}$ \\
\hline 1. & Use correct grammar when speaking to an audience. & 3.55 \\
\hline 2. & Use an appropriate business vocabulary when speaking to an audience (e.g. appropriate greeting or introduction). & 3.73 \\
\hline 3. & Establish rapport with the audience (e.g. audience attention or involvement, and appropriate greeting or introduction). & 3.75 \\
\hline 4. & Use appropriate voice qualities when speaking to an audience (e.g. fluid and natural with good articulation and volume). & 3.88 \\
\hline 5. & Establish eye contact with the audience. & 3.95 \\
\hline 6. & $\begin{array}{l}\text { Use appropriate body language and poise when speaking to an audience (e.g. engaging, use of gestures and expressions } \\
\text { to enhance presentation). }\end{array}$ & 3.92 \\
\hline 7. & Demonstrate my command of material when speaking to an audience (e.g. no reading, express ideas in own words). & 3.92 \\
\hline 8. & Understand the material appropriately (e.g., accuracy of statements and coverage of topic) & 4.08 \\
\hline 9. & Organize the material appropriately (e.g. used an introduction, body, and conclusion). & 3.90 \\
\hline 10. & Present myself in a professional manner to an audience (e.g. appropriate dress and demeanor). & 3.67 \\
\hline
\end{tabular}

*5-point scale, where 1 is strongly disagree, 3 is neither agree nor disagree, and 5 is strongly agree

\section{APPENDIX - COMMENTS ON ORAL SKILLS}

Over 500 comments describing the importance of communication skills were collected by Christensen and Rees (2002). The following sample focuses on the importance of oral communication skills.

- $\quad$ Accountant/Firm Management. Business vocabulary is more important in the "real business world" than you would ever thought imaginable.

- Controller. I place strong emphasis on communications skills in my organization. The most important commodity accountants provide to their clients and customers is information. As such, the ability to communicate information, whether through writing, formal speaking, or casual conversation, is extremely important. I feel very strongly that college and university programs do not emphasize this critical attribute with their students.

- CPA, Partner. Without question, there is consistent lack in writing skills in almost all recent graduates. Oral communications skills are also lacking. There is no question in my mind that more emphasis must be placed on these skills in undergraduate study.

- CPA. I believe colleges could do a better job at preparing graduates to communicate with peers and laypeople on complex technical issues, both written and oral.

- CPA. In most cases, our only contacts with clients are either in written or oral communications. It is extremely important that those communications be correct and proper.

- Director, Financial Planning. Clear thinking and effective communication are as or more important than debits and credits. I am acquainted with many smart young people who accomplish little because of poor communication skills.

- $\quad$ Director, SEC Compliance \& Reporting. I just completed an internship program with a graduate student. He presented himself well during the interview and has worked part-time in accounting functions. However, I was astounded at his attitude of what work was appropriate for him and what was beneath him. He was self-acknowledged that he was poor in grammar, was not proficient with a calculator, and was a poor proofreader. He was not proficient at grammar (did not know what an apostrophe was). He did not listen to instructions. His objective was to "work on Wall Street." He constantly used the phrase "me 'n Jane" went.... I was tempted to respond, "Me want you to stop talking."

- $\quad$ Manager, Internal Tax Consulting Group. Oral and written skills seem to be lacking in people that have many years of experience. Although there is always room for improvement as we progress through our professions, developing a foundation of these competencies at the formal education level is certainly an achievable goal.

- Manager. I would like to see a greater emphasis at the college level to teach business communication skills - written and oral. Every graduate should be able to compose a letter that is well written and concise. Every graduate should be able to stand before his/her peers and present a presentation with poise. 
- Manager. It is amazing to me that young college graduates do not recognize the importance of verbal and written communications skills. In the public accounting profession, these individuals are our first line of contact with our clients. Their skills in these areas are vital to how our clients perceive the firm as a whole.

- Manager. The most important oral skills are being able to converse with the client in a professional and appropriate manner along with being able to clearly communicate questions and "status reports" on the work performed to supervisors.

- Managing Partner. The communication skills of current college graduates are disappointing. They seem to be getting worse, not better.

- OMB Administrator. Based on my experience with the performance of accounting graduates, I have concluded that accounting students need to have both oral and written communications as part of the curriculum. Currently upon graduation, accounting graduates know very little about effective and efficient communications.

- Partner. Both written and oral communications have become a lost subject for colleges and all other educational institutions. Some, but not all, college graduates appear to be barely literate.

- $\quad$ Partner. Today's accounting graduates don't know how to write, speak, and worst of all, listen to superiors and ask appropriate questions. They lack the skill to go get the data they need through verbal or written inquiry from superiors or client personnel. Accounting fundamentally requires excellent communication skills, writing, speaking, and listening. Somehow, we need to figure out how to get the classroom to mimic the work environment where the ability to communicate and "get the work done quickly and accurately" is most prized.

- Partner. Written and oral communication is extremely important in today's business environment. It is $90 \%$ of the job!

- President. I can't emphasize enough how important writing and verbal skills are in staff development. A large part of our audit field work is verbally communicating with the client, then turning around and writing up the work performed in succinct prose. I do not hire people who aren't strong in written and verbal skills. It reflects badly on our firm in the eyes of the client. Plus, in order for a staff person to take on engagement supervisory responsibility, he or she needs to be able to communicate effectively with the client in order for the client to be comfortable with that person being in charge of their account. I can also say that most people at our firm, including myself, have become more effective communicators because of our continued emphasis on these skills.

- Principal. My responses seem to be somewhat negative, but I feel strongly that better preparation can be made in these areas - especially in oral presentations. Some don't even know how to stand, shuffle their feet, act nervous, exercise poor posture, etc. New hires must be able to think and compose on the keyboard. If they are drafting in handwritten form, they are wasting valuable time.

- Tax Compliance Manager. The top 3 communication skills required are effective telephone communication, e-mail writing, and letter writing. In today's "connected" work environment, clients and client service teams are spread all across the country. The new staff must be able to effectively and proactively express ideas, ask questions, and receive guidance and training over the telephone.

- Tax Manager. The written and oral skills of both employees and students are at an all time low. Proper English, whether written or oral, appears to be a relic of the past. 
Notes 